\title{
PENGARUH KUALITAS PRODUK TERHADAP LOYALITAS PELANGGAN PADA COUNTER ANDRIS RELOAD CELLULAR MADIUN
}

\author{
Alfian Sigit Permana \\ Mahasiswa Prodi Pendidikan Ekonomi IKIP PGRI Madiun
}

\begin{abstract}
This study aims to determine the quality of the product in Counter Andris Reload Cellular Madiun, to determine the level of customer loyalty in Counter Andris Reload Cellular Madiun, and to know is there any effect of product quality on customer loyalty in Counter Andris Reload Cellular Madiun. The samples in this study using saturated sample as many 45 people without regard to existing strata in the population. Data collection using questionnaires and documentation. The research design used in this study was a descriptive correlational design. In the statistical methods used to analyze the data with the regression formula and product moment correlation. The results showed that the quality of products have influence at the same time a positive relationship to customer loyalty in Counter Andris Reload Cellular Madiun. It is derived from the value of 0.724 while the value $r_{\text {count }}$ and $r_{\text {table }}$ 0.294 (0.724 $\geq 0.294)$. By this means Ha acceptable product quality has a relationship with customer loyalty in Counter Andris Reload Cellular Madiun. It also obtained the value of the $\mathrm{F}$ test, $\mathrm{F}_{\text {count }}$ at 47,372 while $\mathrm{F}_{\text {table }}$ of $4.06(47,372 \geq 4.06)$. This means that there is rejection of $\mathrm{H} 0$ which indicates that there are significant between product quality on customer loyalty in Counter Andris Reload Cellular Madiun. By this means Ha received no difference between the effect of product quality on customer loyalty in Counter Andris Reload Cellular Madiun.
\end{abstract}

Keywords: Quality Product, Customer Loyalty

\begin{abstract}
Abstrak: Penelitian ini bertujuan untuk mengetahui kualitas produk di counter Andris Reload Seluler Madiun, untuk menentukan tingkat loyalitas pelanggan di counter Andris Reload Seluler Madiun, dan untuk mengetahui apakah ada pengaruh kualitas produk terhadap loyalitas pelanggan di counter Andris Reload Seluler Madiun . Sampel dalam penelitian ini menggunakan jenuh sampel sebanyak 45 orang tanpa memperhatikan strata yang ada dalam populasi. pengumpulan data menggunakan kuesioner dan dokumentasi. Desain penelitian yang digunakan dalam penelitian ini adalah desain deskriptif korelasi. Dalam metode statistik yang digunakan untuk menganalisis data dengan rumus regresi dan korelasi product moment. Hasil penelitian menunjukkan bahwa kualitas produk memiliki pengaruh pada saat yang sama hubungan positif terhadap loyalitas pelanggan di counter Andris Reload Seluler Madiun. Hal ini berasal dari nilai 0,724 sedangkan nilai rcount dan rtabel $0,294(0,724 \geq 0,294)$. Dengan ini berarti Ha kualitas produk yang dapat diterima memiliki hubungan dengan loyalitas pelanggan di counter Andris Reload Seluler Madiun. Hal ini juga diperoleh nilai uji F, Fhitung di 47.372 sementara Ftabel dari 4,06 (47.372 $\geq$ 4,06). Ini berarti bahwa ada penolakan $\mathrm{H} 0$ yang menunjukkan bahwa ada yang signifikan antara kualitas produk terhadap loyalitas pelanggan di counter Andris Reload Seluler Madiun. Dengan ini berarti Ha diterima ada perbedaan antara pengaruh kualitas produk terhadap loyalitas pelanggan di counter Andris Reload Seluler Madiun.
\end{abstract}

Kata kunci: Kualitas produk, Loyalitas Pelanggan 


\section{PENDAHULUAN}

Perkembangan teknologi yang semakin maju membawa manusia untuk dapat melakukan segala hal secara instan. Salah satu contoh adalah dalam dunia komunikasi. Surat-menyurat tidaklah suatu hal yang menjadi jalan satu-satunya untuk melakukan komunikasi jarak jauh, namun dengan adanya ponsel manusia dapat melakukan komunikasi jarak jauh dengan sangat mudah. Selain dapat digunakan untuk komunikasi jarak jauh, ponsel juga memiliki banyak kegunaan lainnya, salah satunya untuk melakukan akses internet.

Perkembangan ponsel semakin lama semakin meluas, bahkan sekarang ini dapat dikatakan setiap orang memiliki ponsel. Namun dengan demikian, perlu diingat bahwa ponsel tidak akan dapat digunakan tanpa adanya kartu perdana selular, sehingga muncul perusahaan-perusahaan yang memproduksi kartu perdana selular.

Melihat kondisi perusahaan kartu perdana yang semakin lama semakin berkembang, hal ini menjadi ladang bisnis bagi para pengusaha perseorangan untuk mendirikan usaha dibidang counter selular yang menjual berbagai macam produk kartu perdana selular. Salah satunya adalah Counter Andris Reload Selular yang berada di jalan jatisiwur Kecamatan Taman kota Madiun.

Seiring perkembangan bisinis counter selular yang semakin lama semakin banyak yang bermunculan membuat persaingan semakin tinggi pula. Porter (dalam Fandy Tjiptono dan Anastasia Diana, 2001: 65) Pada dasarnya setiap perusahaan menghadapi lima kekuatan atau faktor persaingan yaitu pesaing dalam industri yang sama, bargaining power pemasok, bargaining power pembeli, ancaman pendatang baru, dan ancaman dari produk substitusi.

Melihat lingkungan yang terus berkembang dan cepat berubah, faktor kunci keberhasilan untuk bertahan hidup di pasar bergantung pada hubungan jangka panjang antara pemasok dan pembeli. Sehingga tantangan untuk semua pemasar yang sedang dihadapi saat ini adalah bagaimana meningkatkan loyalitas pelanggan.

Loyalitas pelanggan merupakan hal yang terpenting dalam kegiatan suatu usaha. Menurut Kotler dan Keller (2009: 153) berpendapat bahwa menciptakan hubungan yang kuat dan erat dengan pelanggan adalah mimpi semua pemasar dan hal ini sering menjadi kunci keberhasilan pemasaran jangka panjang. Imbalan dari loyalitas bersifat jangka panjang dan kumulatif.

Menurut oliver (dalam Ratih Hurriyati, 2008: 129) loyalitas pelanggan adalah komitmen pelanggan bertahan secara mendalam untuk berlangganan kembali atau melakukan pembelian ulang produk atau jasa terpilih secara konsisten dimasa yang akan datang. Sedangkan menurut Ujang Sumarwan (2011: 391) loyalitas pelanggan adalah sikap positif seorang konsumen terhadap suatu merek, konsumen memiliki keinginan kuat untuk membeli ulang produk yang sama pada saat sekarang maupun masa datang.

Karakteristik pelanggan yang loyal menurut Griffin (2003: 31) adalah orang yang melakukan pembelian ulang secara teratur, membeli antar lini produk atau saja, mereferensikan ke orang lain, menunjukkan kekebalan terhadap tarikan dari pesaing.

Adapun keuntungan pelanggan yang loyal, menurut W. Reinartz V.Kumar (dalam Jenu Widjaja Tandjung, 2014: 117) yaitu :

1) Biaya melayani pelanggan loyal akan lebih murah. Hal ini disebabkan pelanggan lebih mengenal proses transaksi.

2. Pelanggan yang loyal akan membayar harga lebih mahal. Hal ini memungkinkan apabila biaya perpindahan cukup besar.

3. Pelanggan loyal akan mempromosikan perusahaan. Pelanggan loyal diharapkan akan mempromosikan perusahaan kepada orang lain.

Dengan adanya tingkat loyalitas pelanggan yang tinggi, maka pelanggan akan 
melakukan pembelian secara terus-menerus dan membawa dampak yang menguntungkan bagi perusahaan." Semakin lama loyalitas seorang pelanggan, semakin besar laba yang dapat diperoleh perusahaan dari satu pelanggan ini"(Griffin, 2003: 11). Sedangkan menurut Gunawan Adisaputro (2010: 44) "Pelanggan yang setia akan melakukan pembelian ulang sehingga pelanggan yang setia menjadi sumber keuntungan jangka panjang".

Menurut Kotler dan Keller (2009: 153) Perusahaan yang ingin membentuk ikatan pelanggan yang kuat harus memperhatikan hal-hal sebagai berikut :

1) Menciptakan produk atau jasa yang unggul.

2) Menciptakan kepuasan dan retensi pelanggan.

3) Mempermudah pelanggan menjangkau perusahaan.

4) Mengakses informasi tentang kebutuhan pelanggan.

Membangun loyalitas pelanggan lebih mudah dan membutuhkan biaya yang lebih sedikit dibandingkan dengan mencari pelanggan baru yang membutuhkan dana lebih besar. Dengan demikian perusahaan harus memiliki strategi yang tepat untuk membangun tingkat loyalitas pelanggannya. Pada dasarnya pelanggan menginginkan kualitas produk yang dibelinya sesuai dengan permintaannya, sehingga perusahaan untuk membangun tingkat loyalitas pelanggannya harus berorientasi pada kualitas produk. John F. Welch (dalam Kotler dan Keller, 2009: 143) menyatakan bahwa kualitas adalah jaminan terbaik atas loyalitas pelanggan, pertahanan terbaik kami menghadapi para pesaing dari luar, dan satu-satunya jalan menuju pertumbuhan dan pendapatan yang langgeng.

Kualitas produk (product quality) adalah salah satu sarana positioning utama pemasar. Kualitas mempunyai dampak langsung pada kinerja produk atau jasa; oleh karena itu, kualitas berhubungan erat dengan nilai dan kepuasan pelanggan, dalam arti yang lebih sempit, kualitas bisa didefinisikan bebas dari kerusakan." (Kotler dan Armstrong, 2008: 272). Sedangkan Menurut American Society for Quality Control (dalam Ririn Tri Ratnasari dan Mastuti, 2011: 103-104) menyatakan kualitas adalah keseluruhan dari ciri-ciri dan karakteristik-karakteristik dari suatu produk atau jasa dalam kemampuannya untuk memenuhi kebutuhan-kebutuhan yang telah ditentukan atau bersifat laten.

Fandy Tjiptono dan Anastasia Diana (2000: 70) menyatakan bahwa manfaat dari kualitas yang superior antara lain yaitu :

1) Loyalitas pelanggan yang lebih besar.

2) Pangsa pasar yang lebih besar.

3) Harga saham yang lebih tinggi.

4) Harga yang lebih tinggi.

5) Produktivitas yang lebih besar.

Untuk mencapai kualitas produk yang diinginkan maka diperlukan suatu standarisasi kualitas. Cara ini dimaksudkan untuk menjaga agar produk yang dihasilkan memenuhi standar yang telah ditetapkan sehingga pelanggan tidak akan kehilangan kepercayaan terhadap produk yang bersangkutan. Pemasar yang tidak memperhatikan kualitas produk yang ditawarkan akan menanggung tidak loyalnya pelanggan. Namun apabila pemasar memperhatikan kualitas, maka pelanggan tidak akan berpikir panjang untuk melakukan pembelian terhadap produk tersebut sehingga dapat menciptakan loyalitas konsumennya.

Menurut Joseph S. Martinich (dalam Zulian Yamit, 2005: 11) Dimensi kualitas produk untuk mengukur tingkat kualitas produk yaitu :

1) Performance. Hal yang paling penting bagi pelanggan adalah apakah kualitas produk menggambarkan keadaan yang sebenarnya atau apakah pelayanan diberikan dengan cara yang benar.

2) Range and Type of Features. Selain fungsi utama dari suatu produk dan pelayanan, pelanggan sering kali tertarik pada kemampuan atau keistimewaan 
yang dimiliki produk dan pelayanan.

3) Reliability and Durability. Kehandalan produk dalam penggunaan secara normal dan berapa lama produk dapat digunakan hingga perbaikan diperlukan.

4) Maintainable and Serviceability. Kemudahan untuk pengoperasian produk dan kemudahan perbaikan maupun ketersediaan komponen pengganti.

5) Sensory Characteristics. Penampilan, corak, rasa, daya tarik, bau, selera, dan beberapa faktor lainnya mungkin menjadi askpek penting dalam kualitas.

6) Ethical Profile and Image. Kualitas adalah bagian terbesar dari kesan pelanggan terhadap produk dan pelayanan.

Dimensi kualitas tersebut berpengaruh pada pelanggan. Jika pelanggan menerima produk dan pelayanan melebihi harapannya, maka pelanggan akan mengatakan produk dan pelayanannya berkualitas dan jika kenyataannya pelanggan menerima produk dan pelayanan kurang atau sama dari harapannya, maka pelanggan akan mengatakan produk dan pelayanannya tidak berkualitas atau tidak memuaskan.

Dengan adanya kualitas produk yang baik, yang diberikan oleh perusahaan kepada pelanggannya, maka loyalitas pelanggan akan meningkat pula. Sehingga dapat memberikan keuntungan jangka panjang bagi perusahaan tersebut.

\section{METODE PENELITIAN}

Penelitian ini dilaksanakan di Counter Andris Reload Cellular Madiun. Dengan alamat Jalan Jatisiwur Kelurahan Demangan, Kecamatan Taman, Kota Madiun. Waktu penelitian ini dilaksanakan selama 6 bulan, mulai bulan Februari 2014 sampai dengan Juli 2014.

Adapun pertimbangan peneliti memilih tempat penelitian ini, diantaranya: 1) Counter Andris Reload Cellular Madiun menarik untuk diteliti, 2) Belum pernah ada penelitian tentang kualitas produk terhadap loyalitas pelanggan pada Counter Andris Reload Cellular Madiun.

Sebelum melakukan penelitian, dibuat rancangan penelitian sesuai masalah. Menurut Hamid Darmadi (2011: 253-254), menjelaskan bahwa perencanaan penelitian tidak lain adalah gambaran secara mendetail tentang proses penelitian yang akan dilakukan oleh peneliti untuk dapat memecahkan suatu permasalahan. Perencanaan penelitian pada umumnya berisi komponen-komponen penelitian yang secara komprehensif menggambarkan urutan tindakan yang harus dilakukan untuk mencapai tujuan penelitian. Sedangkan desain penelitian adalah bagian dari perencanaan yang menunjukkan usaha peneliti dalam melihat apakah model testing data yang dilakukan mempunyai validitas yang komprehensif yang mencakup validitas internal maupun eksternal.

Metode penelitian yang digunakan dalam penelitian ini adalah metode penelitian Kuantitatif. Menurut Sugiyono (2010: 14), menyatakan bahwa penelitian kuantitatif dapat diartikan sebagai metode penelitian yang berlandaskan pada filsafat positivisme, digunakan untuk meneliti pada populasi atau sampel tertentu, teknik pengambilan sampel pada umumnya dilakukan secara random, pengumpulan data menggunakan instrumen penelitian, analisis data bersifat kuantitatif/ statistik dengan tujuan untuk menguji hipotesis yang telah ditetapkan.

Dalam penelitian kuantitatif ini desain yang digunakan adalah desain penelitian deskriptif korelasional. Menurut Notoatmojo (dalam Ida dan Wardiyah, 2006: 20) penelitian deskriptif korelasional adalah penelitian yang diarahkan untuk menjelaskan hubungan antara dua variabel, yaitu variabel bebas dengan variabel terikat.

\section{Variabel Penelitian}

Variabel penelitian adalah suatu atribut atau sifat atau nilai dari orang, obyek, atau 
kegiatan yang mempunyai variasi tertentu yang ditetapkan oleh peneliti untuk dipelajari dan kemudian ditarik kesimpulannya (Sugiyono, 2013: 61). Dalam penelitian ini yang menjadi variabel bebas (X) adalah kualitas produk, sedangkan variabel terikat (Y) adalah loyalitas pelanggan.

Adapun definisi operasional variabelvariabel tersebut adalah sebagai berikut:

1. Kualitas produk (product quality) adalah salah satu sarana positioning utama pemasar. Kualitas mempunyai dampak langsung pada kinerja produk atau jasa; oleh karena itu, kualitas berhubungan erat dengan nilai dan kepuasan pelanggan, dalam arti yang lebih sempit, kualitas bisa didefinisikan bebas dari kerusakan (Kotler dan Armstrong, 2008: 272).

2. Loyalitas Pelanggan adalah pelanggan yang melakukan pembelian ulang secara teratur, pelanggan yang membeli produk dari lini produk yang lain, pelanggan yang mereferensikan kepada orang lain, pelanggan yang tidak dipengaruhi oleh pesaing untuk pindah (Jenu Widjaja Tandjung, 2004: 121).

\section{Populasi, Sampel, Teknik Pengambilan Sampel}

Dalam suatu penelitian tidak lepas dari adanya populasi, yaitu merupakan keseluruhan unti yang akan diteliti. Sugiyono (2013: 117) menyatakan bahwa populasi adalah wilayah generalisasi yang terdiri atas obyek/subyek yang mempunyai kualitas dan karakteristik tertentu yang ditetapkan oleh peneliti untuk dipelajari dan kemudian ditarik kesimpulannya. Populasi dalam penelitian ini adalah pelanggan yang datang di Counter Andris Reload Cellular Madiun.

Sampel adalah bagian dari populasi. Nanang Martono (2010: 74) menyatakan bahwa sampel merupakan bagian dari populasi yang memiliki ciri-ciri atau keadaan tertentu yang akan diteliti. Sampel dalam penelitian ini adalah pelanggan yang datang di Counter Andris Reload Cellular Madiun pada tanggal 21 Mei 2014 sampai dengan 27 Mei2014.

Teknik pengambilan sampel yang digunakan dalam penelitian ini adalah teknik sampel jenuh. Menurut Sugiyono (2013: 124-125) Sampling jenuh adalah teknik penentuan sampel bila semua anggota populasi digunakan sebagai sampel.

\section{Teknik Pengumpulan Data}

Teknik pengumpulan data yang digunakan peneliti dalam melakukan penelitian adalah:

1. Kuesioner

Menurut Supardi (2005: 127) angket adalah sejumlah pertanyaan secara tertulis yang akan dijawab oleh responden penelitian, agar peneliti memperoleh data lapangan/empiris untuk memecahkan masalah penelitian dan menguji hipotesis yang telah ditetapkan. Jumlah soal dalam angket ini adalah 20 soal yang terbagi dalam 2 variabel yang akan diteliti. 10 soal untuk variabel kualitas produk (X) dan 10 soal untuk variabel loyalitas pelanggan $(\mathrm{Y})$.

2. Dokumentasi

Metode ini peneliti mencari dan mendapatkan data-data primer dengan melalui data-data dari prasasti-prasasti, naskahnaskah kearsipan (baik dalam bentuk barang, cetakan, maupun rekaman), data gambar/foto/blue print dan lain sebagainya (Supardi, 2005: 138). Peneliti menggunakan metode ini untuk memperoleh data yang menunjang data penelitian, seperti profil Counter Andris Reload Cellular dan produk-produk yang dijual.

\section{Instrumen Penelitian}

Instrumen yang digunakan dalam penelitian ini adalah berupa kuesioner dengan pertanyaan tertutup. Menurut Supardi (2005: 133) pertanyaan tertutup yaitu model pertanyaan dimana pertanyaan tersebut telah disediakan jawabannya, sehingga responden hanya memilih dari alternatif jawaban yang 
sesuai dengan pendapat atau pilihannya. Sistem pemberian skor berdasarkan Skala Likert. Sugiyono (2013: 134) menyatakan bahwa Skala Likert digunakan untuk mengukur sikap, pendapat, dan persepsi seseorang atau sekelompok orang tentang fenomena sosial.

\section{Teknik Analisis Data}

Sebelum melakukan penelitian instrumen dalam hal ini yaitu kuesioner harus diuji terlebih dahulu keabsahannya dengan menggunakan uji validitas. Uji validitas berguna untuk mengetahui apakah ada pertanyaan-pertanyaan pada kuesioner yang harus dibuang atau diganti karena dianggap tidak relevan. Setelah di uji validitasnya, kuesioner tersebut kemudian diuji reliabilitasnya. uji reliabilitas berguna untuk menetapkan instrumen yang dalam hal ini kuesioner apakah dapat digunakan lebih dari satu kali, paling tidak oleh responden yang sama.

Untuk uji hipotesis, dalam penelitian ini menggunakan teknik analisis regresi linier sederhana dengan menggunakan uji $r$, uji f, dan uji t. Uji $r$ digunakan untuk menguji pengaruh antara variabel satu dengan variabel lainnya. Variabel yang dimaksud adalah variabel independen yaitu kualitas produk $(\mathrm{X})$ dan variabel dependen yaitu loyalitas pelanggan (Y). Uji f digunakan untuk mengetahui apakah semua variabel independen (X) berpengaruh signifikan terhadap variabel dependennya (Y). Sedangkan uji t digunakan untuk mengetahui apakah variabel independen (X) secara individu mempunyai pengaruh yang signifikan terhadap variabel dependen (Y).

\section{HASIL PENELITIAN}

Gambaran Umum Counter Andris Reload Cellular

Counter Andris Reload Cellular Madiun bertempat di Jalan Jatisiwur Kelurahan Demangan Kecamatan Taman Kota Madiun. Counter ini didirikan pada tahun 2004. Pendirinya Bapak Andri Wasis Sudibyo S.E. Counter ini menjual berbagai produk-produk operator selular serta aksesoris handphone. Selain itu counter Andris Reload Cellular merupakan salah satu agen penjualan pulsa elektrik di Madiun yang melayani penjualan pulsa elektrik seluruh area nasional.

\section{Variabel Kualitas Produk}

Deskripsi dari variabel kualitas produk, dengan jumlah data $(\mathrm{N})$ sebanyak 45 orang mempunyai deskripsi data sebagai berikut : SS sebanyak 82, S sebanyak 220, N sebanyak 130, TS sebanyak 18, STS sebanyak 0 . Sehingga dapat disimpulkan bahwa Counter Andris Reload Cellular Madiun memberikan kualitas produk yang cukup baik terhadap pelanggannya.

\section{Variabel Loyalitas Pelanggan}

Deskripsi dari variabel loyalitas pelanggan, dengan jumlah data $(\mathrm{N})$ sebanyak 45 orang mempunyai deskripsi data sebagai berikut : SS sebanyak 73, S sebanyak 242, N sebanyak 119, TS sebanyak 16, STS sebanyak 0 . Sehingga dapat disimpulkan bahwa loyalitas pelanggan pada Counter Andris Reload Cellular cukup baik.

\section{Hasil Uji Validitas dan Reliabilitas Kualitas Produk}

Hasil uji validitas angket kualitas produk yang terdiri dari 10 soal yang di uji cobakan kepada pelanggan Counter Andris Reload Cellular Madiun yang berjumlah 10 pelanggan dapat dikatakan bahwa 10 soal tersebut semuanya valid. Hal ini dapat dilihat dari hasil uji validitas yang menunjukkan bahwa nilai $r_{x y} \geq r_{\text {tabel }}$.

Hasil uji reliabilitas angket kualitas produk yang terdiri dari 10 soal yang di uji cobakan kepada pelanggan Counter Andris Reload Cellular Madiun yang berjumlah 10 pelanggan dapat dikatakan bahwa 10 soal tersebut reliabel. Hal ini dapat dilihat dari hasil uji reliabilitas yang menunjukkan 
bahwa nilai $r_{\text {hitung }} \geq r_{\text {tabel }}$.

\section{Hasil Uji Validitas dan Reliabilitas Loyalitas Pelanggan}

Hasil uji validitas angket loyalitas pelanggan yang terdiri dari 10 soal yang di uji cobakan kepada pelanggan Counter Andris Reload Cellular Madiun yang berjumlah 10 pelanggan dapat dikatakan bahwa 10 soal tersebut semuanya valid. Hal ini dapat dilihat dari hasil uji validitas yang menunjukkan bahwa nilai $r_{x y} \geq r_{\text {tabel }}$.

Hasil uji reliabilitas angket loyalitas pelanggan yang terdiri dari 10 soal yang di uji cobakan kepada pelanggan Counter Andris Reload Cellular Madiun yang berjumlah 10 pelanggan dapat dikatakan bahwa 10 soal tersebut reliabel. Hal ini dapat dilihat dari hasil uji reliabilitas yang menunjukkan bahwa nilai $r_{\text {hitung }} \geq r_{\text {tabel }}$.

\section{Hasil Uji Hipotesis \\ Hasil Analisis Regresi Linier Sederhana}

Diperoleh persamaan garis regresi linier sederhana $Y=13,165+0,658 X$. Dari persamaan tersebut dapat dinyatakan apabila kualitas produk (X) meningkat sebesar 1\% maka loyalitas pelanggan (Y) akan meningkat sebesar 0, 658\% apabila faktor lain dianggap tetap.

\section{Hasil Uji Korelasi}

Dari hasil uji korelasi didapat besarnya nilai $r_{\text {hitung }}$ sebesar 0,724 sedangkan $r_{\text {tabel }}$ dengan jumlah responden 45 dan probabilitas 0,05 sebesar 0,294. Hal ini berarti nilai $r_{\text {hitung }} \geq r_{\text {tabel }}$ $(0,724 \geq 0,294)$. Atas dasar uji korelasi tersebut dapat disimpulkan bahwa Ha terima Ho tolak, artinya bahwa ada hubungan yang signifikan antara kualitas produk terhadap loyalitas pelanggan di Counter Andris Reload Cellular Madiun.

\section{Hasil Uji f}

Dari hasil perhitungan uji $\mathrm{f}$ diperoleh nilai $f_{\text {hitung }}$ sebesar 47,372 , sedangkan nilai $f_{\text {tabel }}$ dengan jumlah responden 45 dan probabilitas
0,05 sebesar 4,06 . Hal ini berarti $f_{\text {hitung }} \geq f_{\text {tabel }}$ $(47,372 \geq 4,06)$. Sehingga dari hasil uji $\mathrm{f}$ tersebut dapat disimpulkan bahwa $\mathrm{Ha}$ terima Ho tolak, artinya bahwa ada pengaruh antara kualitas produk terhadap loyalitas pelanggan di Counter Andris Reload Cellular Madiun.

\section{Hasil Uji t}

Dari hasil perhitungan uji t diperoleh nilai $t_{\text {hitung }}$ sebesar 6,88264 , sedangkan nilai $t_{\text {tabel }}$ dengan jumlah responden 45 dan probabilitas 0,05 sebesar 1,68107 . Hal ini berarti $t_{\text {hitung }} \geq t_{\text {tabel }}(6,88264 \geq 1,68107)$. Sehingga dari hasil uji $t$ diatas dapat disimpulkan bahwa Ha terima, Ho tolak, artinya bahwa ada beda pengaruh antara kualitas produk terhadap loyalitas pelanggan di Counter Andris Reload Cellular Madiun.

\section{Simpulan Hasil Analisis}

Atas dasar hasil pengujian hipotesis dapat diambil simpulan sebagai berikut.

\section{Simpulan Uji Korelasi}

Hasil uji korelasi di dapat besarnya nilai $r_{\text {hitung }}$ sebesar 0,724 sedangkan $r_{\text {tabel }}$ dengan jumlah responden 45 dan probabilitas 0,05 sebesar 0,294. Hal ini berarti nilai $r_{\text {hitung }} \geq r_{\text {tabel }}$ $(0,724 \geq 0,294)$. Atas dasar uji korelasi diatas dapat disimpulkan bahwa Ha terima Ho tolak, artinya bahwa ada hubungan kualitas produk terhadap loyalitas pelanggan di Counter Andris Reload Cellular Madiun.

\section{Simpulan Uji f}

Dari hasil perhitungan uji $\mathrm{f}$ diperoleh nilai $f_{\text {hitung }}$ sebesar 47,372 , sedangkan nilai $f_{\text {tabel }}$ dengan jumlah responden 45 dan probabilitas 0,05 sebesar 4,06 . Hal ini berarti $F_{\text {hitung }} \geq F_{\text {tabel }}(47,372>4,06)$. Sesuai hipotesis yang diajukan dapat diperoleh simpulan bahwa ada pengaruh kualitas produk terhadap loyalitas pelanggan pada Counter Andris Reload Cellular Madiun. 


\section{Simpulan Ujit}

Dari hasil perhitungan uji t diperoleh nilai $t_{\text {hitung }}$ sebesar 6,88264 , sedangkan nilai $t_{\text {tabel }}$ dengan jumlah responden 45 dan probabilitas 0,05 sebesar 1,68107 . Hal ini berarti $t_{\text {hitung }} \geq t_{\text {tabel }}(6,88264 \geq 1,68107)$. Sehingga dari hasil uji $t$ diatas dapat disimpulkan bahwa Ha terima, Ho tolak, artinya bahwa ada beda pengaruh antara kualitas produk terhadap loyalitas pelanggan di Counter Andris Reload Cellular Madiun.

\section{PENUTUP}

\section{Simpulan}

Berdasarkan hasil analisis data pada pembahasan pengaruh kualitas produk terhadap loyalitas pelanggan di Counter Andris Reload Cellular Madiun, maka dapat diambil kesimpulan sebagai berikut :

1. Counter Andris Reload Cellular Madiun selalu memberikan kualitas produk yang baik kepada pelanggannya. Hal ini dapat dilihat dari hasil analisis kuesioner terhadap 45 pelanggan bahwa diperoleh jawaban: SS sebanyak 82, S sebanyak 220, N sebanyak 130, TS sebanyak 18 , STS sebanyak 0 . Sehingga dapat disimpulkan bahwa Counter Andris Reload Cellular Madiun memberikan kualitas produk yang cukup baik terhadap pelanggannya.

2. Loyalitas pelanggan di Counter Andris Reload Cellular adalah baik. Hal ini dapat dilihat dari hasil analisis kuesioner terhadap 100 pelanggan bahwa diperoleh jawaban : SS sebanyak 73, S sebanyak 242, N sebanyak 119, TS sebanyak 16, STS sebanyak 0. Sehingga dapat disimpulkan bahwa loyalitas pelanggan pada Counter Andris Reload Cellular cukup baik.

3. Kualitas produk mempunyai pengaruh terhadap loyalitas pelanggan pada Counter Andris Reload Cellular Madiun. Hal ini dapat dilihat dari:

a. Uji Regresi, yaitu $\mathrm{Y}=13,165+$ $0,658 X$. artinya apabila kualitas produk meningkat sebanyak $1 \%$, maka loyalitas pelanggan akan meningkat sebesar 0,658, apabila faktor lain dianggap tetap.

b. Uji Korelasi, yaitu bahwa $r_{\text {hitung }}$ sebesar 0,724 sedangkan rtabel dengan probabilitas 0,05 dengan jumlah responden 45 sebesar 0,294. Hal ini menunjukkan $r_{\text {hitung }} \geq r_{\text {tabel }}(0,724$ $\geq 0,294)$. Artinya ada hubungan kualitas produk terhadap loyalitas pelanggan di Counter Andris Reload Cellular Madiun.

c. Uji F, yaitu $F_{\text {hitung }}$ sebesar 47,372, sedangkan $F_{\text {tabel }}$ dengan probabilitas 0,05 dengan jumlah responden 45 sebesar 4,06. Hal ini menunjukkan $F_{\text {hitung }} \geq F_{\text {tabel }}(47,372 \geq 4,06)$. Artinya ada pengaruh antara kualitas produk terhadap loyalitas pelanggan di Counter Andris Reload Cellular Madiun.

d. Uji t, yaitu $t_{\text {hitung }}$ sebesar 6,88264, sedangkan $t_{\text {tabel }}$ dengan probabilitas 0,05 dengan jumlah responden 45 sebesar 1, 68107. Hal ini menunjukkan $\mathrm{T}_{\text {hitung }} \geq \mathrm{T}_{\text {tabel }}(6,88264 \geq 1,68107)$. Artinya ada beda pengaruh antara kualitas produk terhadap loyalitas pelanggan di Counter Andris Reload Cellular Madiun.

\section{Saran}

Berdasarkan kesimpulan yang diperoleh didalam penelitian, maka peneliti mengajukan saran kepada counter dan peneliti selanjutnya sebagai berikut :

1. Bagi Counter Andris Reload Cellular

Diharapkan Counter Andris Reload Cellular Madiun dapat mempertahankan loyalitas pelanggannya. Agar dapat memberikan keuntungan dalam jangka panjang.

2. Bagi Peneliti Selanjutnya

Diharapkan untuk penelitian selanjutnya, agar peneliti dapat menambah variabel X, 
karena selain kualitas produk masih banyak faktor-faktor lain yang dapat mempengaruhi loyalitas pelanggan.

\section{DAFTAR PUSTAKA}

Fandy Tjiptono dan Anastasia Diana. 2001. Total Quality Manajement (TQM). Yogyakarta: Andi Offset.

Kotler, Philip dan Keller, Kevin Lane. 2009. Manajemen Pemasaran. Terjemahan oleh Bob Sabran. 2008. Jakarta: Gelora Aksara Pratama.

Ratih Hurriyati. 2008. Bauran Pemasaran dan Loyalitas Konsumen. Bandung: Alfabeta.

Ujang Sumarwan. 2011. Perilaku Konsumen : Teori dan Penerapannya dalam Pemasaran. Bogor: Ghalia Indonesia.

Griffin, Jill. Tanpa tahun. Customer Loyalty : Menumbuhkan dan Mempertahankan Kesetiaan Pelanggan. Terjemahan oleh Dwi Kartini Yahya. 2003. Jakarta: Penerbit Erlangga.

Jenu Widjaja Tandjung. 2004. Marketing Manajement : Pendekatan pada Nilainilai Pelanggan. Malang: Bayumedia Publishing anggota IKAPI Jatim.
Gunawan Adisaputro. 2010. Manajemen Pemasaran : Analisis Untuk Perancangan Strategi Pemasaran. Yogyakarta: Unit Penerbit dan Percetakan Sekolah Tinggi Ilmu Manajemen YKPN.

Kotler, Philip dan Armstrong, Gary. 2008. Prinsip-prinsip Pemasaran. Terjemahan oleh Bob Sabran. 2008. Jakarta: Gelora Aksara Pratama

Ririn Tri Ratnasari dan Mastuti H. Aksa. 2011. Teori dan Kasus Manajemen Pemasaran Jasa. Bogor: Ghalia Indonesia.

Zulian Yamit. 2005. Manajemen Kualitas Produkdan Jasa. Yogyakarta: Ekonisia.

Hamid Darmadi. 2013. Dimensi-dimensi Metode Penelitian Pendidikan dan Sosial. Jakarta: Alfabeta.

Sugiyono. 2013. Metode Penelitian Pendidikan (Pendekatan Kuantitatif, Kualitatif, dan R\&D). Bandung: Alfabeta.

Nanang Martono. 2012. Metode Penelitian Kuantitatif : Analisis Isi dan Analisis Data Sekunder. Jakarta: Rajagrafindo Persada.

Supardi. 2005. Metodologi Penelitian Ekonomi \& Bisnis. Yogyakarta: UII Press. 